Article

\title{
Does Collaboration Lead to Sustainability? A Study of Public-Private Partnerships in the Swedish Mountains
}

\author{
Therese Bjärstig \\ Department of Political Science, Umeå University, 90187 Umeå, Sweden; therese.bjarstig@umu.se; \\ Tel.: +46-702-161-268
}

Received: 23 August 2017; Accepted: 20 September 2017; Published: 21 September 2017

\begin{abstract}
The conflicts that frequently manifest in the Swedish mountains often stem from the use and preservation of natural resources. Resistance against protected area proposals, protests concerning the management of large carnivores, the felling of old-growth forests, and disputes over who should be allowed to hunt or fish are all commonplace. There are currently strong trends, both in national and international policy making, towards leaning on various forms of collaborative governance arrangements to deal with such policy failures. Consequently, various forms of partnerships have been initiated to promote more sustainable practices in the mountain regions of Sweden. To what extent has the creation of these collaborative partnerships in natural resource management improved policy output and sustainability outcomes? To examine the issue, data was extracted from 47 semi-structured interviews with 39 project leaders and eight county officials, with the sample randomly selected from a database of 245 public-private collaborative projects in the Swedish mountains. The results indicate that partnerships do lead to improved sustainability, especially when it comes to social outcomes. However, there is a need for more systematic follow-ups by practitioners, particularly on ecological outcomes, where the country administrative boards should take a leading role and facilitate such evaluations in the future.
\end{abstract}

Keywords: collaboration; public-private partnership; policy output; outcomes; sustainability; follow-up; evaluation; natural resource management; Swedish mountains

\section{Introduction}

The United Nations Conference held in Rio de Janeiro in 1992 popularized a view of sustainability as comprising ecological, economic, and social dimensions [1], which led to an increased interest in the social aspects of sustainability [2]. In parallel, a revival of ideas related to deliberative democracy and the representation of interest groups took place, during which traditional forms of top-down government systems were increasingly replaced with, or complemented by, collaborative forms of governance [3,4]. Collaborative governance is one particular form of decentralized governance that can be defined as: "A governing arrangement where one or more public agencies directly engage non-state stakeholders in a collective decision-making process that is formal, consensus-oriented, and deliberative, and that aims to make or implement public policy or manage public programs or assets" [5] (p. 2). There is a theoretical expectation that collaborative governance should result in "better" decisions and policy outcomes by engaging previously marginalized actors in a consensus-based, deliberative process [6,7]. Accordingly, collaboration is a promising mechanism for managing stakeholder conflicts, as it presumably enhances the efficiency of the decision-making process through reducing transaction costs, improving the legitimacy of decisions, and increasing the sustainability of resources and livelihoods [8,9]. However, much of the literature has so far focused on the collaborative process itself rather than its outcomes [10]. 
There is considerable faith among stakeholders that collaborative arrangements are a "good thing" [6,11]. Data from the Swedish Mountain Mistra survey in 2004 showed that $65 \%$ of the Swedish population supported local or co-management of protected areas [12], and between $50 \%$ and $85 \%$ thought that stakeholders such as municipalities, the Swedish Society for Nature Conservation, hunters, and Sami reindeer herders should have a say in large carnivore management [13]. According to these reports, the support is even higher in mountain regions, which can be interpreted as constituting a favorable context for collaboration. A considerable amount of research has consequently looked into the evolvement of collaborative arrangements in natural resource management in the Swedish mountain regions, but so far, only specific management areas such as protected areas [12,14-16], large carnivores [17,18], reindeer herding [19,20], hunting and fishing [21-24], snowmobiling [25], and water management [26] have been considered.

The above-mentioned studies have identified and analyzed a number of "hot spot" cases, focusing on case-specific drivers and procedural aspects, in combination with survey analyses of attitudes. Some research has also contributed to the development of participatory methods [27]. However, there is a lack of research on a wider scale; in other words, there is a need for research that gathers overarching empirical evidence to support more generalized claims that collaboration does indeed lead to sustainable outcomes $[5,28]$. Thus, the aim of this paper is to examine whether collaborative arrangements in public-private partnerships (Public-private partnerships are here defined as: "collaborative arrangements in which actors from two or more spheres of society (state, market, and/or civil) are involved in a non-hierarchical process, and through which these actors strive for a sustainability goal" [29] (p. 77). The term public-private partnership and the terms public-private collaboration, public-private collaboration project, and public-private project are used interchangeably in the text, all implying that actors from both public and private spheres are engaged and interacting [30]) in natural resource management are perceived by the main actors to improve policy output and sustainability outcomes in the Swedish mountains-and if so, in what ways? As stated earlier, much of the collaborative governance literature has so far mainly focused on input and procedural factors, while only a few authors have focused on sustainability outcomes. Thus, this paper addresses not only a theoretical gap, but also a pressing empirical question [10,28].

The choice of studying Sweden is justified by two main reasons. First, Sweden is generally considered a pioneering state in implementing sustainable development [31,32]; accordingly, Sweden can be regarded as a best-case example. Second, the long-lasting tradition of consensus-oriented politics between public and private actors in Sweden is well known internationally [33], which makes Sweden both an interesting and representative case. Following this, experiences from public-private initiatives in natural resource management in the Swedish mountains can be used to shed light on how sustainability outcomes can be promoted by public-private partnerships in other countries with similar socio-economic contexts, i.e., sparsely populated areas rich in natural resources.

\section{Output and Outcome Factors for Sustainability}

The analytical point of departure is taken in collaborative governance, which is an increasingly used term in the literature concerning natural resource management $[5,34,35]$. The advantage of this starting point is that it includes contextual variables (socio-economic, ecological, and civil society relationships, and institutional arrangements, such as power relations and political dynamics) and process variables (the characteristics of emerging institutional arrangements such as representativeness/participation, deliberation, and leadership). Outcomes-whether political outcomes or perceived or real changes in ecological and/or socio-economic conditions-can be explained as the result of the interaction of these forces. Process improvements are increasingly being seen as necessary precursors to environmental improvements, but just measuring the former is not enough [36]: it is important to assess whether the underlying problems are being solved and activities are being carried out (i.e., goal fulfilment/output), and whether the ecological, economic, and social conditions have improved (i.e., sustainability outcomes). 
The focus in this paper is on the actual performance of public-private partnerships operating in the Swedish mountains, i.e., on their "output" and "outcomes". Thomas and Koontz [37] (p. 99) have divided output into intermediate outputs (early products and services delivered from a process, e.g., a completed plan), and end outputs (final products and services delivered, e.g., implemented projects in a plan, compliance monitoring and enforcement). Outcomes have accordingly also been divided into intermediate outcomes (changes outside a process that precede the desired end result, e.g., patterns of resource use), and end outcomes (desired goals, e.g., changes in environmental conditions). However, this paper will not use the distinction intermediate outputs and outcomes, since they are perceived as an integral part of the end outputs and outcomes, and are hard to separate analytically in a stringent way in the empirical material due to the heterogeneous base of natural resource collaborations.

According to Koontz and Thomas [38], outcomes can be divided broadly into two types: social and ecological. In this paper, economic outcomes are added in order to give a more comprehensive assessment of sustainability. Indeed, the concept of sustainable development has evolved and broadened since the 1987 Brundtland definition, and hence it is in keeping with this development that three dimensions of sustainable development are underlined here:

1. Social, which means respecting human rights and equal opportunities for all in society. It requires an equitable distribution of benefits, with a focus on alleviating poverty. There is an emphasis on local communities: maintaining and strengthening their life support systems, recognizing and respecting different cultures, and avoiding any form of exploitation. Accordingly, social outcomes include social capital, trust, enhanced equity, and improved living standards $[37,39,40]$.

2. Ecological, which means conserving and managing resources, especially those that are not renewable or are precious in terms of life support. It requires action to minimize pollution of air, land, and water, and to conserve biological diversity and natural heritage. Ecological outcomes include natural resource conditions such as water quality, fish stocks, biodiversity, the enhancement of green infrastructure, the prevention of soil erosion, etc. [37,41].

3. Economic, which means generating prosperity at different levels of society and addressing the cost effectiveness of all economic activity. Crucially, it is about the viability of enterprises and activities, and their ability to be maintained in the long term. Economic outcomes include the viability of local enterprises, efficiency and technical improvements, employment opportunities, and available funding sources [42].

It is important to appreciate that the three sustainability dimensions are in many ways interdependent, and that they can be both mutually reinforcing and conflicting; thus, delivering sustainable development means striking a balance between them [43].

\section{Materials and Methods}

\subsection{Research Design, Study Area and Background Context}

This study builds upon 39 semi-structured interviews with representatives from public-private collaborative projects conducted from 2014 to 2016, and eight in-depth interviews with key officers in the four mountain county administrative boards conducted in 2014 (see Appendix A). An extensive quantitative examination of a database comprising detailed information on 245 funded projects, all aimed at public-private collaboration over natural resource management in the four counties (see Figure 1), resulted in the random selection of the 39 projects for further analysis (see Eckerberg, Bjärstig and Zachrisson [44] for more information on the original compilation of the database of these 245 projects). This random sample of public-private projects makes it possible to discuss the results on a more aggregated level and move away from single case studies of "hot spots".

The selection of the respondents who represent the 39 public-private collaborative projects was based on the official contact information of project leaders, or alike. The respondents represent a mix of public (14 respondents) and private (25 respondents) actors. Municipality officers were the most 
common respondents among the public actors. This is probably because only municipalities can apply for funding through local initiatives for nature protection (LONA) projects. Additionally, these officers were often engaged in the projects both as a responsible officer and as an individual member in the private organisations collaborating with the municipality. Thus, complementary interviews were conducted with eight key officials at the four mountain country administrative boards in order to balance, triangulate, and validate the material from the public-private collaborative projects at the local level.

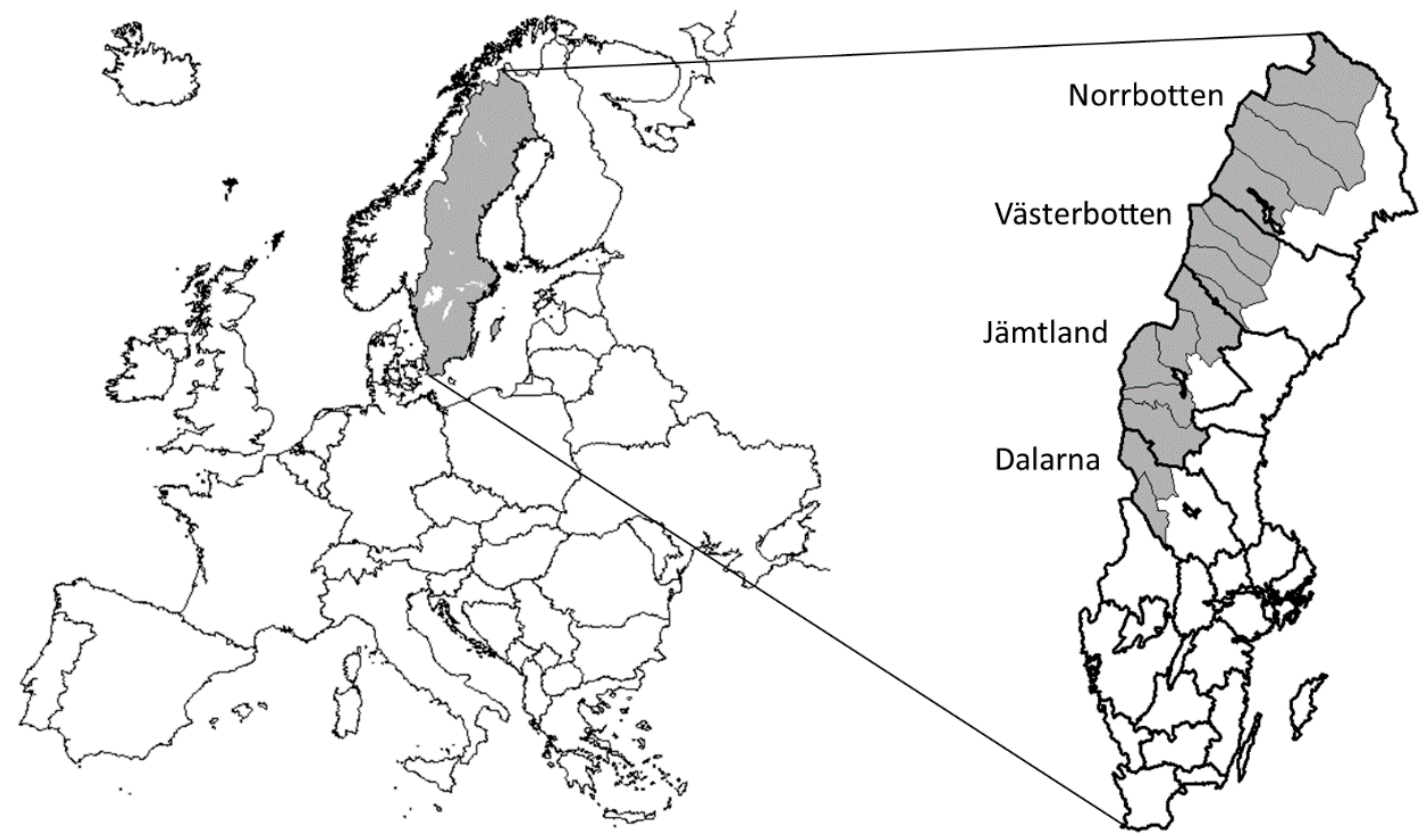

Figure 1. Map showing the location of the four mountain counties in Sweden: the 15 mountain municipalities included in the study are marked in grey.

The total area of the 15 mountain municipalities is over $155,000 \mathrm{~km}^{2}$, nearly $30 \%$ of the total area of Sweden, and they currently hold $1.4 \%$ of the total population in Sweden, out of about 9.7 million. Large parts of the area are protected land. Forestry is carried out on nearly all productive forest land, which is owned predominantly by forest companies, non-industrial private forest owners, and the state. Eight of the 12 large river systems are mostly used for hydropower production. Wind power farms are being built, the mining industry is expanding, and recreational activities (hunting, fishing, hiking, skiing, snow mobile driving, etc.) are carried out on privately-owned land, as well in commercial contexts on all types of land, based on property rights and the right of public access. The Sami have cultural rights and rights to self-determination in traditional territories, including the mountain region. Reindeer husbandry is ongoing across the whole mountain area.

The database of 245 public-private collaborative projects that the random sample in this paper was rendered from contains a series of natural resource projects divided into 16 different themes: tracks and access, recreation, fishing, nature and culture, tourism, nature protection, process, water, forest, local development, Sami and reindeer, landscape, wind energy, hunting, climate and energy, and mining (see Figure 2. More detailed information on these themes can be found in Eckerberg, Bjärstig and Zachrisson [44]). 


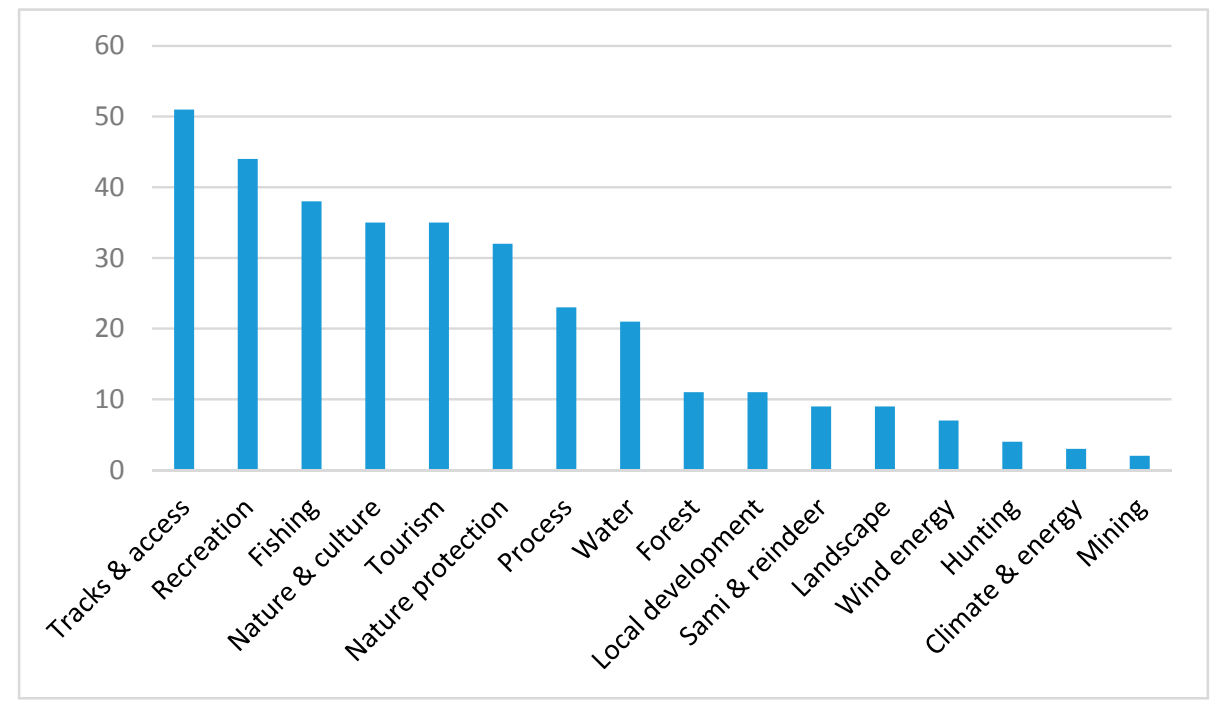

Figure 2. Themes for public-private collaborations on the management of natural resources in the Swedish mountains ( $n=245$, but some projects cover two themes).

The majority of these themes (all except hunting and mining) are represented in the 39 projects considered in this paper (see Appendix A for an overview of the projects and the type of natural resource theme they represent). The type and degree of collaboration differs somewhat between the mountain counties. Very few of the collaborative projects concern major business and/or economic activities such as climate and energy, wind energy, hunting, and mining; it is worth noting that compulsory and institutionalized consultation is already taking place to avoid and/or handle conflicts in those fields [44].

The partnerships in this paper represent different natural resource management issues as well as different collaboration strategies and structures, and they have accomplished various practical measures to different degrees. Most of the collaborations in this paper are practically oriented, i.e., aiming at compilations of (local) knowledge and inventories, development and/or reviews of (management) plans, writing of project applications, engagement in courses/training activities, information activities, and/or physical measures (e.g., construction of shelters, bridge repairing, restoration efforts, etc.). However, some of them are development projects that are seeking to promote economic growth and new forms of organization/collaboration.

In the result sections, the 39 cases are handled and analyzed collectively (rather than providing in-depth descriptions of single collaborations/themes and their specific circumstances). As already stated, this is done in an attempt to move away from single case studies of "hot spots": the purpose is to allow for discussions of general trends and patterns regarding outputs and sustainability outcomes in the mountain areas based on the main actors' perceptions.

\subsection{Semi-Structured Interviews}

A questionnaire for semi-structured interviews was developed and thoroughly tested (see Appendix B). The questionnaire contains four overarching themes developed from the integrative framework for collaborative governance [34]. The framework seeks to explain policy outputs and outcomes in terms of perceived and real changes. The themes include the context (the type of natural resource(s), measures of trust, etc.), the initiation (whose initiative, perceptions of policy failure, available funding sources, institutional design, etc.), the process dynamics (the use of consensus, the level of exchange and deliberation, etc.), and the outputs and outcomes (goal fulfillment, new management practices, including eventual monitoring and enforcement, changed ecological, economic, and social conditions). The latter theme is the main focus of this paper. The questions regarding results, concrete 
outputs, and perceived goal fulfillment in the 39 studied projects are the base for the results presented in Section 4.1 and Figure 3, while the overarching question and sub-questions regarding sustainability outcomes of the collaborations are the base for the results presented in Section 4.2 and Figure 4. Figure 5 is the authors' compilation of the answers regarding sustainability outcomes and goal fulfillment. The purpose of Figure 5 is to display the degree of simultaneous improvements in one or several sustainability dimensions generated by the collaborations.

The semi-structured interviews were mainly conducted over the telephone (two interviews were done face-to-face), and they reflect both the top-down and bottom-up aspects of collaboration, with representatives of the county administrative boards, municipalities, and representatives of local collaborative arrangements all consulted. All interviews were recorded and transcribed [45].

The interview transcripts were read closely, and all of the answers were coded manually in accordance with the different themes and questions in the interview manual. The material was then compiled as a dataset that made it possible to make quantitative comparisons. General trends and patterns were identified and analyzed qualitatively in a thematic content analysis [46,47]. Quotes are used here to illustrate the perceptions of the respondents regarding the output and outcomes.

The study is actor-oriented, and the starting point for the paper is the respondents' perceptions of the outputs and outcomes of the collaborations. The project objectives are not traced back to project applications or reports, but are rather captured by the respondents' descriptions of the objectives and the outputs, and in relation to the respondents' perceptions of goal fulfillment. In a manner that follows logically from this, the measures of environmental outcomes are not based on strictly defined ecological measures of environmental conditions, but rather on the respondents' perceptions of environmental improvement. There are clearly some drawbacks to using this methodology, since it will be a subjective rather than objective measure of environmental conditions, and there is also a risk of a "halo effect" [37]. The use of perceptions also raises concerns about potential biases whereby participants who buy into a process may overestimate the success of that project $[40,48,49]$. However, the present author believes that stakeholder opinion is useful as a "second-best approximation" [40] (p. 241), and it is used as such in this study. Perceptions are assumed to give an overall picture of the collaborations' goal fulfillment/outputs and outcomes, and the perceptions are confirmed to some extent by the respondents' willingness to continue to collaborate and engage in natural resource management. Further, interviews with key officials at the county administrative boards are used to triangulate and validate the respondents' perceptions.

\section{Results}

\subsection{Project Objectives and Goal Fulfillment-Outputs}

Almost all projects report some kind of output, most commonly in terms of information activities, knowledge summaries/inventories, and different forms of physical measures. To get a more profound picture of the output, the extent to which the respondents felt that the project objective/s originally set had been achieved was examined (see Figure 3). In over half (56\%) of the projects, the objectives had clearly been reached, according to the respondents (predominantly in the collaborations with practically-oriented objectives aiming at concrete actions). In $16 \%$ of the projects, the originally set project objective/s had been only partly achieved, according to the respondents. This might be because some of the collaborations were still ongoing, and planned activities had yet to be implemented. This made it problematic for the respondents to accurately assess the goal fulfillment and output. Another explanation for this figure could be that the project had been running for some time (or had developed into more of a permanent collaboration), and the initial objectives had been altered and/or reformulated. In collaborative projects where the aim was to write an application, i.e., the project was a preparatory study, and where the application was under review or not yet decided on, the respondents had difficulty in reporting on goal fulfillment and output. Nevertheless, regardless of 
whether the application was to be approved or not, they had produced an application, and hence a tangible output.

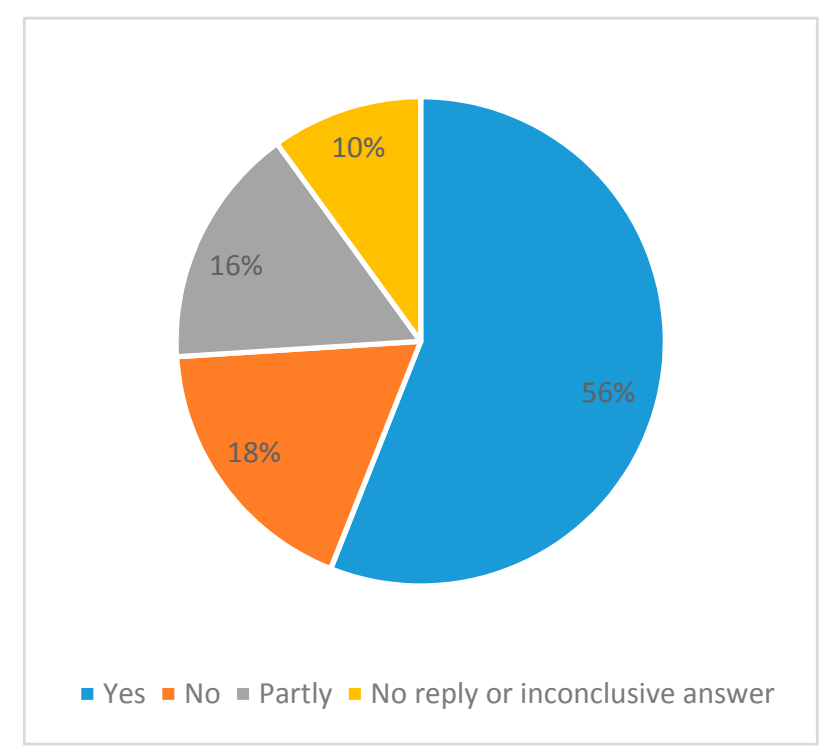

Figure 3. Perceived goal fulfillment in public-private collaborations on natural resources $(n=39)$.

In $18 \%$ of the collaborations, the objectives had not been reached, according to the respondents: "No, we have not seen any results yet; one measure was taken in June this year and I think it may take quite some time before you see any effects. On the other hand, the other measure produced effects at once. It is quite complex, because it is not certain [whether] a migration barrier [in the example of fish] is an obstacle all the time-it may only be so at some water levels" (Interview 2). The reasons put forward by the respondents for not reaching the objectives are lack of time (too short a time period to say something about the output), administrative/technical problems, lack of resources, natural/physical circumstances (seasonal variations, e.g., snow cover, ice on lakes and rivers, water stands, etc.), illness/death, personal circumstances, and conflicts. Some projects just did not fall out as planned, without a forthcoming reasonable explanation. There are also collaborations that were perceived not to have any output at all: "... it [the public-private collaboration] resulted in nothing really, if someone from outside would look at it. We had a lot of meetings, and the social aspect has been extremely valuable. We have strengthened the ties, and we can trust each other when it blows" (Interview 5). In this example, no outputs were put forward, but still the project was perceived to have an outcome in terms of increased social sustainability. This will be elaborated further in Section 4.2.

About $10 \%$ of the respondents did not want to respond, or could not respond, since they had not been part of the collaboration from the beginning and/or did not remember. In some cases, the answer was inconclusive and could not be interpreted by the researcher.

The output of most collaborations seems to consist of physical measures and knowledge production. New knowledge often emerges as an output, and this knowledge is of different types, ranging from ecological and/or biological inventories drawn from local history/culture, to knowledge of collaborating and understanding of other actors' views and needs. Collaboration in itself is often described as a learning process. Overall, projects built on collaboration appear to be an important means to achieve concrete results: "The project is not primarily a collaborative project but a restoration project, where collaboration is an important part of achieving the goals" (Interview 13).

However, in more than a third of the projects, the respondents indicated that collaboration is important only in certain contexts, such as when there is a serious lack of confidence/trust either between different local actors or between locals and authorities. Some of these respondents said that 
there are too few players involved in the local community to cover external requests for collaboration (the sparsely populated mountain areas are characterized by long distances; traveling $200-400 \mathrm{~km}$ to meetings is not uncommon). They also mention that they do not have, or are not given, enough time or other resources to collaborate: "We are trying to push municipalities to show what benefits there are in collaboration, but it can be experienced as a pain among local authorities. For them to get something out of collaboration, it takes resources at the beginning to start up, and if they have a shortage of resources, it's seen as a hassle that someone nags all the time; 'Can we meet' and 'Can we get together and start up this and that'" (Interview 6).

When the empirical material is triangulated, it becomes obvious that there are somewhat different views among private and public collaborators when it comes to the importance of having enough time: a private actor asserted, "You cannot rush an increased understanding just because you have money; it must be allowed to take the time needed. One should never have that urgency as we felt that the county administrative board had from the beginning; they wanted it to go fast" (Interview 33). Another private actor endorsed this view: " ... it's happened relatively little if you compare with the project application [e.g., in relation to the project objective/s and concreate output]. It takes time" (Interview 34). Whereas in contrast, the public actor notes: "Yes, from our government perspective it has taken too long. But it is because we are attentive since the locals have said that they need all this time since they want to explore all opportunities, and to educate themselves [...] We learn while we're at it. It is so obvious to us that if we did not have good relations to start up a conversation, then you are not reaching our goal. If you want results, then you have to add this time, and the more you know each other and all the actors, the faster things go" (Interview 36).

Respondents emphasized that it is important that collaboration is not just about discussions without tangible output. Several of the respondents with a more critical view also mentioned that the pressure to collaborate can be particularly high in certain cases; for example, for the reindeer herders and the Sami villages, and for small business entrepreneurs, who have very limited possibilities to engage. One of the respondents summed up the prerequisites for successful collaboration like this: "... one thing is that there must be a mutual need to collaborate. Secondly, the collaboration must be about a question that actually can be solved by collaboration. And thirdly, there must be resources for carrying out long-term collaboration. And in this respect political support is important. Then there must be time enough to build confidence" (Interview 6).

\subsection{Sustainability Outcomes}

Generally, the respondents believe that collaboration on managing natural resources in the Swedish mountains has generated positive outcomes for all aspects of sustainability.

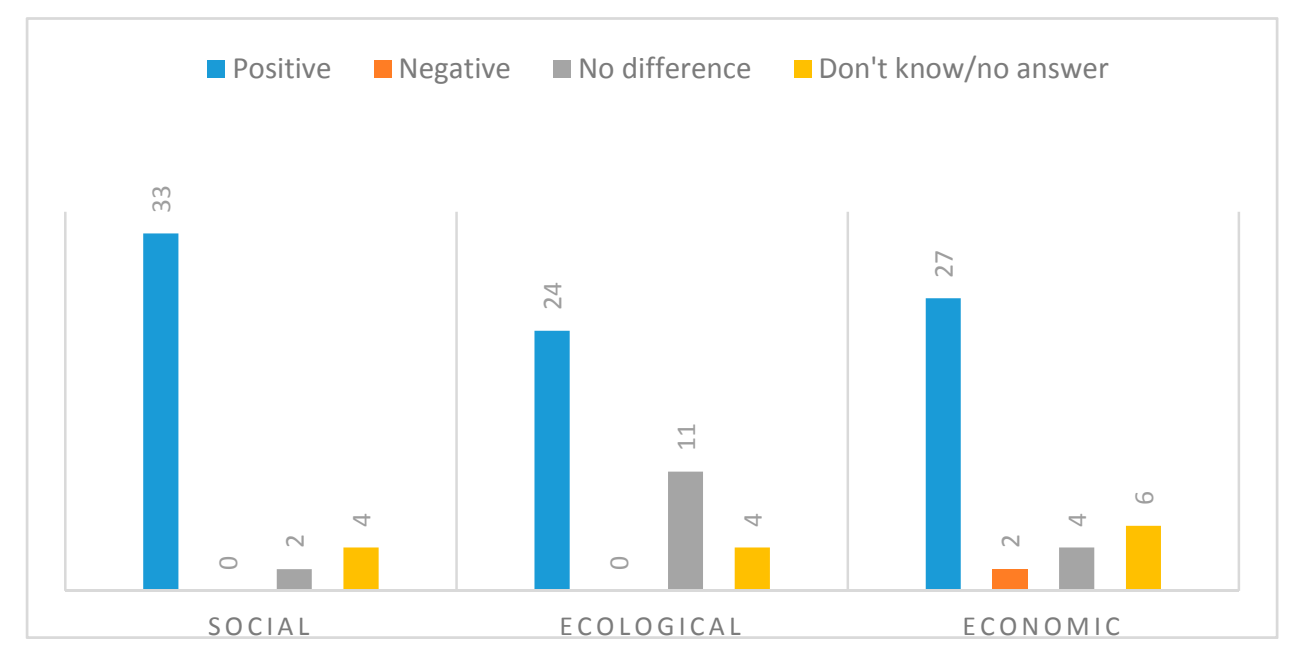

Figure 4. How collaboration was perceived to have affected the different sustainability dimensions, i.e., sustainability outcomes $(n=39)$. 
As displayed in Figure 4, the social dimension was perceived to have been strengthened to a higher degree than the other two sustainability dimensions. Several respondents mentioned that collaboration has increased their confidence and trust in the other collaborators. The partners in the collaboration might not always agree, but they understand and respect the other actors' positions better than before because of the collaboration. Many times, a well-functioning collaboration also led to continued collaboration by the established partnership in other projects: "... the cooperation has been so good that we have made a new project application with the same partners" (Interview 13). Ecological outcomes were in many cases experienced as positive, but in some projects, no difference had yet been discerned. One plausible explanation for this is that ecological restoration efforts and nature conservation activities require considerable time before any concrete results can be detected, and such results are often quite difficult to measure and monitor without sufficient expertise. Another explanation is that some of the projects did not consider the ecological dimension in their objectives. The only sustainability dimension that displayed a negative development, albeit only in a small number of projects, was the economic dimension. Above all, the hope that local collaboration could lead to new job opportunities and/or increased tourism was not realized, and in one project, people lost the money that they invested when the plan was not approved: " ... they leased the ground during these years as this process was going on. Also, they have provided money to us, and considerable sums to produce these preparatory documents. So, of course, they have invested quite a lot of money in the preparatory work and did not get any return from it" (Interview 21). Accordingly, the economic outcomes are perceived as negative, and in some projects, the respondents answered that no difference could be detected.

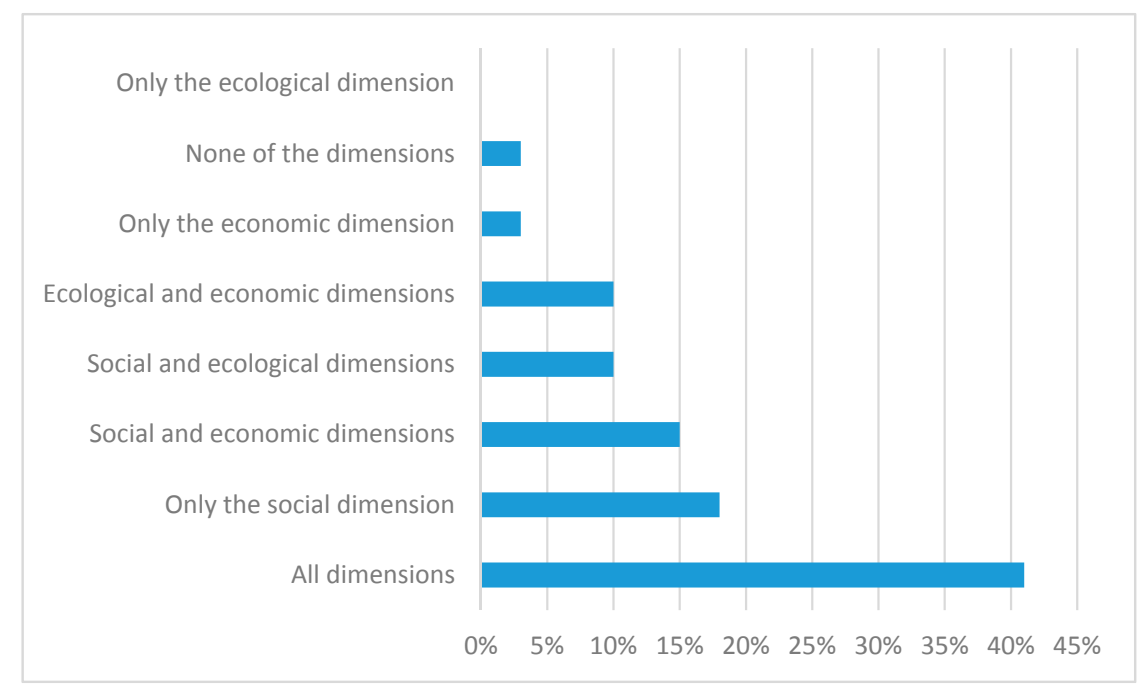

Figure 5. Sustainability dimensions perceived to have improved because of collaboration $(n=39)$.

The vast majority of the respondents perceived positive outcomes in all three sustainability dimensions (see Figure 5), but have not necessarily considered all of the dimensions in their project objectives. This is mostly due to what they describe as indirect outcomes. The following may be considered an example of indirect outcomes. By improving a track, the pressure from tourists in a sensitive landscape is channeled and the disturbance to plants and animals minimized; this is referred to as an indirect environmental outcome. However, as the improved track attracts more tourists, and people stay at the local hotel more often than before and shop locally, which is perceived to strengthen the local economy, an indirect economic outcome also emerges. One respondent, speaking in relation to their work on improving tracks for snowmobiles, explained it like this: "Yes, especially for the environment, because we now can control the paths for snowmobiles to a greater degree. The forest owners are very happy, they get much less destruction of plants - that, in the long run, benefits them economically as well as the society" (Interview 35). There is an awareness and reflectiveness among many of the 
respondents on how the sustainability dimensions are interrelated and affect one another: "It is about creating a sustainable tourism industry. We have to take into account the inheritance we received from Mother Earth, otherwise we have no platform to stand on" (Interview 22), or "If you go beyond what nature can withstand, then tourism will decrease" (Interview 4). The importance of striking a balance between all of the sustainability dimensions is also emphasized: "I think it is important that we have a tourist policy where we have sustainability with respect to all three dimensions. Regarding the social dimension, I think it is very important that the tourism development takes the local population and its conditions into account. We also have three reindeer herding communes in the municipality. They operate in areas that you would like to exploit much more, but it must be in a way that works in the long run also for them and nature" (Interview 28).

In nearly half $(41 \%)$ of the collaboration projects, the respondents state that all three dimensions of sustainability had improved (see Figure 5), while the rest perceived improvements for only one or two of the dimensions. Most commonly in these instances, only social sustainability was thought to have improved (18\%), with $15 \%$ perceiving that both social and economic sustainability had improved. These figures may be attributed to there being slightly more public-private collaborations with such project objectives/themes. It may also be related to few projects having a systematic follow-up, and it might be easier for respondents to claim a positive development in terms of social relations and economic development than for the natural environment. One respondent regrets not including quality targets and/or some type of indicators in the objectives that would enable evaluation of the outputs and outcomes: "We have not set any quality goals" (Interview 12). In general, most respondents would like to see more possibilities to follow up on the projects: "The follow-up is actually the final report and the report given to the decision-making group, describing what has been done. There are rarely any systematic follow-ups on these projects [ ... ] There is seldom time for reflection in this project world. And there is no economy for reflection or follow-up. When the project is over, then you have to leave the final report; there is no funding for any costs that may arise after that" (Interview 10). Long-term commitment and resources to continue to manage and/or monitor the issue/area at hand after the project is finished are crucial to gain sustainable outcomes according to the respondents: "... we completed the project according to the plan we had set up, and we achieved the goals that we also set up. But the frustration is that carrying out our projects is not very worthwhile when we find it difficult to find long-term commitment" (Interview 25). In this respect, the respondents would like to see municipalities and county administrative boards taking on responsibility to a much greater degree than they do today.

No project reported only ecological improvement, and only one project was perceived not to have yielded any sustainability outcome at all. Since the social dimension improved in $84 \%$ of the collaboration projects, this paper indicates that it is of particular importance for public-private collaboration on natural resource management in the mountains. However, this is not unexpected, since the collaboration in itself should have an impact on the social relations between the actors involved.

\section{Concluding Discussion}

Policymakers and politicians choose collaborative governance solutions, such as public-private partnerships, since they anticipate that they will improve the design and implementation of policies and programs, and in doing so also improve the policy outputs and outcomes. As shown in this paper, most of the practically-oriented collaborations on natural resources do report tangible outputs, but whether this course of action actually leads to better ecological outcomes is still a major and open question, according to Scott [50]. In line with Ullibarri [10], this study suggests that public-private collaborations have mixed results on outcomes. However, the results presented in this paper clearly indicate that partnerships do lead to sustainable outcomes, but also that it seems to be easier for the respondents to assess social and economic outcomes rather than ecological ones. Regarding the latter, the respondents require-and want-more knowledge and monitoring data to be able to say something. Of the potential outcomes of collaborative processes, we know the least about environmental impacts [38]. This is perhaps not surprising, since a general weakness among many of the public-private collaborations on natural resources are the lack of follow-up activities, systematic 
evaluations, and/or continued management activities after the project has ended. In this respect, the county administrative boards could assist in creating simple follow-up systems when projects have state funding, and ecological sustainability goals are included in the project's objectives. In addition, many of the projects seem to have relatively vague descriptions of possible sustainable outcomes in relation to the project objectives, which could be improved through enlisting different forms of expert support (e.g., on ecological assessments) for the actual project application, and introducing stronger follow-up requirements. However, one major challenge in this respect is how to assess the outcomes, since impact must be measured on different levels and scales, as well as over time. The detection of outcomes (especially ecological ones) can take a very long time, with unintended effects and external variables intervening. Future research is thus needed to continue to look at and develop practical follow-up criteria on all three sustainability dimensions that are easy to implement and use by the involved participants.

As Thomas and Koontz [37] argue, the use of outputs as proxies for outcomes stretches data by assuming that plans, permits and projects that appear environmentally protective do not always necessarily have positive environmental impacts. The opposite could be as true, since unintended environmental outcomes can appear. In other words, sustainability goals can fall short when implemented. As the results in this paper show, collaborative projects sometimes do not have ambitions to meet and/or handle all three sustainability dimensions; quite often they have a single focus, and/or handle only two of the dimensions. However, they still affect and render indirect sustainability outcomes in other dimensions. These unforeseen, unintended, and/or indirect outcomes should also be accounted for in follow-up work.

Public-private collaborative management of natural resources in the Swedish mountains does enhance sustainability outcomes in general (at least, that is the case for the projects studied here), but the social dimension stands out and seems to be central to achieving a successful collaboration. This insight could be used in a more constructive way in the future (not only in Sweden, but also in other countries with similar socio-ecological contexts), for example, by ensuring that trust and collaboration between public and private actors are established in a way that makes everyone feel involved before the authorities, in a later stage, come in with their recommendations and/or particular demands (cf., [51-55]). Once trust has been built, and the different partners clearly see the added value (i.e., that it is a win-win situation) of collaborating, the forms of collaboration can be more easily spread and continue in new processes and projects.

This paper provides empirical evidence for a range of perceived outputs and outcomes of collaborations in terms of various public-private undertakings. However, the measurable impacts of collaboration on environmental quality, economic development, and social benefits still require further evaluation and refining in other contexts and settings, not to mention in other policy areas [cf., 56]. In this respect, the Swedish case, and this particular study, can be an inspiration. Sustainability outcomes can be promoted by initiating and fostering public-private collaborations in sparsely populated rural areas, as well as in other national settings. Accordingly, countries with a weaker tradition of consensus-oriented politics between public and private actors than Sweden can lean on the experiences and results obtained from public-private initiatives in natural resource management in the Swedish mountains in their own efforts to establish collaborations for sustainability.

Acknowledgments: The research was funded by the Swedish Environmental Protection Agency as part of their research program Storslagna fjäll (Magnificent Mountains: www.storslagnafjall.se). I am grateful to Camilla Thellbro who designed the map in Figure 1 and gave valuable input on a first draft, and to my colleagues Katarina Eckerberg and Anna Zachrisson who I have worked closely with in the project Expectations and Impacts of Collaborative Environmental Governance in the Swedish Mountain Region. I also thank the three anonymous reviewers for their helpful comments.

Conflicts of Interest: The author declares no conflict of interest. The founding sponsors had no role in the design of the study; in the collection, analyses, or interpretation of data; in the writing of the manuscript; and in the decision to publish the results. 


\section{Appendix A}

\section{List of respondents from public-private collaboration projects}

Project title, project type/funding form, (theme for collaboration), public or private respondent, interview format, date of the interview.

\section{Norrbotten}

1. Flora i Pite Lappmark, LONA, (nature and culture), Public, telephone interview, 3 May 2015.

2. Projekt Livsmiljöförbättrande åtgärder i Lule Älv, (water), Private, telephone interview, 11 November 2014.

3. Sevärt i Lappland-Arjeplog, LEADER, (tourism), Public, telephone interview, 4 December 2015.

4. Hållbar destinations utveckling, (tourism), Private, telephone interview, 3 March 2015.

5. Leipipir modellskog, (forest), Private, telephone interview, 13 March 2015.

6. COOPENERGY, (climate and energy), Private, telephone interview, 4 March 2015.

7. Fisketurismutveckling, LEADER, (fishing/tourism), Private, telephone interview, 12 November 2014.

\section{Västerbotten}

8. Vandringsturism i Vindelfjällen, Landsbygdsprojekt, (tracks and access/tourism), Private, telephone interview, 29 October 2015.

9. Friluftsliv i Ammarnäs, LONA, (recreation), Public, written answers, 19 October 2015.

10. Förstudie Fisketurism Från Kust Till Fjäll, Vindelns Kommun LB-fisk, (fish/tourism), Private, telephone interview, 7 November 2014.

11. Vilhelmina Model Forest, (forest), Public, face-to-face interview/pilot, 17 December 2014.

12. Skikkisjön, LONA, (fish/water), Private, telephone interview, 6 November 2014.

13. Vindel River Life, LIFE, (water/fish), Private, telephone interview, 11 November 2014.

14. Regionala landskapsstrategier, (landscape/process), Public, telephone interview, 6 March 2015.

15. Sevärt Lappland i Sorsele kommun, LEADER, (tourism), Public, telephone interview, 22 May 2015.

16. Fiske i Södra Lappland, LEADER, (fish), Public, face-to-face interview, 9 October 2015.

17. Ammarnäsöring—del 2, (fish), Private, telephone interview, 1 February 2016.

18. Naturvårdsprogram för Dorotea kommun, LONA, (nature protection), Public, telephone interview, 1 March 2016.

\section{Jämtland}

19. Skoterprojekt/Projekt spår och leder (EU-projekt Destinationsprojekt), (tracks and access), Private, telephone interview, 5 May 2015.

20. Högforsleden, LEADER, (tracks and access), Private, telephone interview, 5 May 2015.

21. Vindkraftspark Middagsfjället, (wind energy), Private, telephone interview, 29 April 2015.

22. Renens rike, (Sami and reindeer), Private, telephone interview, 11 May 2015.

23. Skoterled Börtnan, LEADER, (tracks and access), Private, telephone interview, 27 April 2015.

24. Fåglar i Västjämtland, LONA, (nature protection), Public, telephone interview, 27 April 2015.

25. GAALTIJE-motor i den samiska turismutvecklingen, (Sami and reindeer/tourism), Private, telephone interview, 23 October 2015.

26. Årevandring, LEADER, (tracks and access), Private, telephone interview, 27 October 2016.

27. Hällingsåfallet Strömsund, LONA, (recreation), Public, telephone interview, 29 January 2016.

28. Fettjeåfallet, LONA, (recreation), Public, telephone interview, 4 February 2016.

29. Vindkraftcentrum.se-Kraften från och för Jämtland, (wind energy), Private, telephone interview, 8 February 2016. 
30. Utveckling av vandringsleder i Ansättfjällen, LONA, (tracks and access), Public, telephone interview, 5 February 2016.

31. Natur och vandringsstig i Näsviken, LONA, (tracks and access), Public, telephone interview, 14 March 2016.

32. Sörbodaprojektet, LEADER, (local development), Private, telephone interview, 9 March 2016.

\section{Dalarna}

33. Förstudie samverkan kring lokal förvaltning och dialog för naturvården i Södra Fjällen, (process/nature protection), Private, telephone interview, 23 June 2015.

34. Lokal hållbar förvaltning av fjällområden, (process), Private, telephone interview, 7 May 2015.

35. SOND Säkerhet och verksamhetsutvecklande skoterledsbro, (tracks and access), Private, telephone interview, 19 October 2015.

36. Dialogprojekt Revidering av skötselplan för Drevfjället "Naturreservat i fjällen i Älvdalens kommun, revidering av beslut och skötselplaner, pilotstudie Drervfjällen", (process), Public, telephone interview, 6 May 2015.

37. Förstudie Grövelsjöfjällen, LEADER, (tourism), Private, written answers, 28 September 2015.

38. Fulufjällets skötselråd, (process/nature protection), Private, telephone interview, 12 May 2015.

39. Fiske-, natur-och kulturstig i Rörbäcksnäs, LEADER, (tracks and access/nature and culture), Private, telephone interview, 19 October 2015. 


\section{Interviews with key officers at the county administrative boards}

Name of the respondent, title/affiliation at the county administrative board, interview format, date of the interview.

\section{Norrbotten}

40. Gustavsson, Erik. Director, Division of Hunting/Reindeer Husbandry, telephone interview, 13 February 2014.

41. Wennström, Britta. Director, Division of Environment, telephone interview, 6 March 2014.

\section{Västerbotten}

42. Eriksson, Torleif. Division of Nature Protection, telephone interview, 21 February 2014.

43. Jonsson, Björn. Director, Division of Nature Protection, telephone interview, 11 March 2014.

\section{Jämtland}

44 Eriksson, Helena. Director, Division of Nature Protection, telephone interview, 14 February 2014.

45 Jonsson, Kristina. Mountain Management Expert, Division of Nature Protection, telephone interview, 11 March 2014.

\section{Dalarna}

46. Svenson, Stig-Åke. Environmental Protection Director, Division of Nature Protection, telephone interview, 12 March 2014.

47. Eriksson, Jemt Anna. Coordinator, Division of Nature Protection, telephone interview, 27 February 2014.

\section{Appendix B}

Interview Manual

Background/initiation

Describe the areas/issues that are the focus of the collaboration.

What do you collaborate on? (Main focus/objectives)

Who participates?

Company

Non-profit organization

Municipality

County administrative board

National authority

Other

What objectives/goals do the participants have, or why do the different actors participate in the collaboration?

Cannot answer the question

All have the same goals

Company

Non-profit organization

Municipality

County administrative board

National authority

Other

How did you reach a common formulation of the objective/goals?

- Worked with a visionary document/project application

Big meeting and/or workshop

Other-what and how? 
Describe when and how this collaborative project emerged.

Who/which organization took the initiative?

Companies

Non-profit organisations

Municipality

County administrative board

National authority

Other

Can the person who initiated the project be described as an eldsjäl [enthusiast, person driven by personal engagement], or was it an ordinary part of the person's engagement/work/duties?

Who/which organizations participated from the start?

\section{Companies}

Non-profit organizations

Municipality

County administrative board

National authority

Other

What was the triggering reason for choosing collaboration? (What is the drive/s for collaboration, e.g., funding possibilities, entrepreneurs, leadership, etc.).

An issue/area that otherwise would not be handled

Shared responsibility/engagement

Policy failure, i.e., unsuccessful management/implementation

Shared economic risks

EU funding

An area/resource with a lot of conflicts

A lot of actors affected

Lack of trust

Disagreement on the knowledge base

Decision based on a previous successful collaboration

Other reason

Did any particular knowledge (local/indigenous) or data stipulate the basis for the collaboration?

What level of trust was there among the partners before the collaboration? What trust/confidence did you have towards the county administrative board?

High levels of trust among the collaboration partners

Low levels of trust among the collaboration partners

High levels of trust towards the county administrative board

Low levels of trust towards the county administrative board

Did the trust levels change during/after the collaboration?

It has increased among the partners

- It has decreased among the partners

- No change/same level among the partners

- It has increased towards the county administrative board

- It has decreased towards the county administrative board

- No change/same level towards the county administrative board 


\section{Collaboration in the specific project/process}

The process (design/organizational aspects).

How did you agree on the design of the collaboration project?

- The design was decided jointly

- The design was decided by a dominant partner

- The design was decided by legislation/regulations

- Nationally

- Internationally

How is the collaboration project organized?

- Steering group/wide network

- Steering group; heterogeneous work-groups

- Steering group; homogenous work-groups

- Steering group and project leader

Other

Why did you organize like this?

- For economic reasons

○ Due to previous experiences

- Trust strategy; to enhance the trust between the parties

- Some of the participants did not have time/resources to collaborate actively

- Due to local conditions

- For environmental reasons

O Other

How often do you meet?

Steering group

O Once a year

○ 1-2 times per half year

O Once a month

Working groups/networks

Once a year

1-2 times per half year

Once a month

- More often than once a month

Open meetings for the public

Once a year

○ 1-2 times per half year

O Once a month

○ Newer

Informal meetings

O Once a year

- 1-2 times per half year 
Once a month

Newer

How do you make decisions?

- Consensus

- Majority decision

○ No legal support for decision making-no decisions

- Fora for discussion/learning process

Have there been any alterations/changes over time?

The form of the collaboration

The number of meetings

Changes in decision making

Were there any conflicts, and in any such cases, how did you handle them?

Conflict/s

No conflicts

Conflicts were not handled

Formalized dialogue and/or neutral facilitator

Took the issue/conflict to another decision level

Other

Involved actors/partners (responsibilities/roles/power).

What roles do the different partners in the collaboration have?

What role do the private partners have?

$\begin{array}{ll}\bigcirc & \text { Facilitator } \\ \bigcirc & \text { Mediator } \\ \bigcirc & \text { Controller } \\ \bigcirc & \text { Leader } \\ \bigcirc & \text { Funder } \\ \bigcirc & \text { Coordinator } \\ \bigcirc & \text { Other }\end{array}$

What role (if any) does the county administrative board have? The municipality? Other authorities?

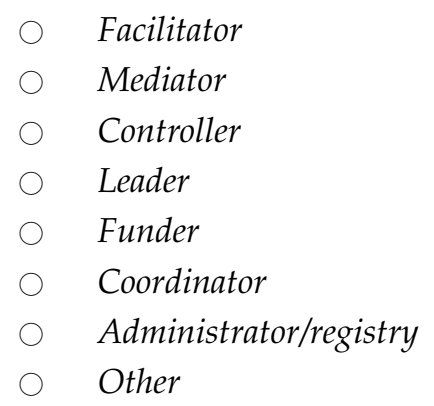

Who/which organizations participate in the concrete measures/actions? Has this changed over time? 


\author{
Business/Company \\ Non-profit organizations \\ Municipality \\ County administrative board \\ National authority \\ Citizen/public \\ Other
}

Have all partners had the same amount of influence/power in the collaboration?

Y Yes

- No

- What actors/partners have been neglected/marginalized/had less influence?

Why?

Anchoring

How is the collaboration anchored in respective groups/associations/organizations?

How do other interested actors get information? The public?

Are there any actors that should participate in the collaboration but do not? Why?

Is it easy/hard to engage participants? Has it altered/changed over time?

Institutional/external context

How is the collaboration project funded?

\title{
EU funding
}

State (national) funding

Regional funding (county administrative board)

Municipal funding

The local actors own work

Private business/companies

Fees to participate in the project

Other funding

\section{Output and outcomes}

What has the collaboration resulted in (i.e., what output)?

What are the concrete outputs?

- Knowledge summaries/inventories

- Plans

- Project applications

- Approved

- Not approved

- Courses/education

Information activities

- Physical measures (building shelters, bridges, etc.)

- Development projects (enhancing economic development locally/regionally)

- New organizational forms (the collaboration project turned into a permanent collaboration, new praxis, etc.)

Other 
What are the outcomes?

Improved conditions regarding the social dimension

Worse conditions regarding the social dimension

Fewer conflicts

More conflicts

Positive business/economic development

Negative business/economic development

Improved conditions for the environment/nature/reindeer ... etc.

Worse conditions for the environment/nature/reindeer ... etc.

New knowledge (what type?)

Increased collaboration in other areas/issues

Other

Are you happy with the results (outputs and outcomes)?

- Me and my organization are satisfied

- Me and my organization are not satisfied

- Other actors are in general satisfied

- Other actors are in general not satisfied

- The public is satisfied

The public is not satisfied

Did the projects reach their initial objectives, i.e., goal fulfillment? Why/why not?

Would the projects' objectives/aims have been reached in any other way with even better results (less cost, faster, etc.)

Has the project been followed up? If so, how?

\section{Other/collaborations in general in the mountains}

How do you perceive collaborations in general?

When is it justified to collaborate more intensively?

Are there any areas/issues that you perceive harder to collaborate on? Why?

Which areas/issues are "easy" to collaborate on? (Is collaboration necessary in such cases?)

How many different collaboration projects/processes do you participate in?

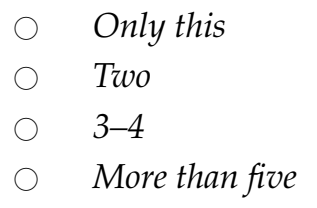

Can you tell me more about these collaborations?

What do you perceive as their main outcomes?

Is participating in numerous collaborations a positive or negative thing?

Do you have something to add regarding collaborations on the management of natural resources in the mountains, something that we have not yet discussed, but that you find important? 


\section{References}

1. UNCED (United Nations Conference on Environment and Development). Agenda 21: Earth Summit-The United Nations Programme of Action from Rio; UNCED: New York, NY, USA, 1992; Available online: http:/ / www.unep.org/Documents.Multilingual/Default.asp?documentid=52\&articleid=61 (accessed on 8 August 2017).

2. Lundqvist, L. Sweden and Ecological Governance: Straddling the Fence; Manchester University Press: Manchester, UK, 2004.

3. Rhodes, R.A. Understanding Governance: Policy Networks, Governance, Reflexivity and Accountability; Open University Press: Maidenhead, UK, 1997.

4. Lundqvist, L.J. Implementation from above: The ecology of power in Sweden's environmental governance. Governance 2001, 14, 319-337. [CrossRef]

5. Ansell, C.; Gash, A. Collaborative governance in theory and practice. J. Public Adm. Res. Theory 2008, 18, 543-571. [CrossRef]

6. Barber, W.F.; Bartlett, R.V. Deliberative Environmental Politics: Democracy and Ecological Rationality; MIT Press: Cambridge, MA, USA, 2005.

7. Smith, G. Deliberative Democracy and the Environment; Psychology Press: Hove, UK, 2003.

8. Margerum, R.D.; Robinson, C.J. Collaborative partnerships and the challenges for sustainable water management. Curr. Opin. Environ. Sustain. 2015, 12, 53-58. [CrossRef]

9. Behnken, J.A.; Groninger, J.W.; Akamani, K. Institutional constraints to collaborative ecosystem management within a wetlands conservation partnership. J. Contemp. Water Res. Educ. 2016, 158, 19-33. [CrossRef]

10. Ulibarri, N. Tracing process to performance of collaborative governance: A comparative case study of federal hydropower licensing. Policy Stud. J. 2015, 43, 283-308. [CrossRef]

11. Fung, A. Putting the public back into governance: The challenges of citizen participation and its future. Public Adm. Rev. 2015, 75, 513-522. [CrossRef]

12. Zachrisson, A. Who should manage protected areas in the Swedish mountain region? A survey approach to co-management. J. Environ. Manag. 2008, 87, 154-164. [CrossRef] [PubMed]

13. Ericsson, G.; Sandström, C. Delrapport Om Svenskars Inställning Till Rovdjurspolitik Och-Förvaltning; FjällMistrarapport: Umeå, Sweden, 2005.

14. Hovik, S.; Sandström, C.; Zachrisson, A. Management of protected areas in Norway and Sweden: Challenges in combining central governance and local participation. J. Environ. Policy Plan. 2010, 12, 159-177. [CrossRef]

15. Zachrisson, A. Commons Protected For or From the People: Co-Management in the Swedish Mountain Region? Ph.D. Thesis, Department of Political Science, Umeå University, Umeå, Sweden, 2009.

16. Zachrisson, A. The designation of Fulufjället National Park: Efficient co-management through downward accountability? Local Environ. 2009, 14, 259-271. [CrossRef]

17. Persson, J.; Zachrisson, A.; Sandström, C.; Ericsson, G. Lokal Förvaltning av Stora Rovdjur: En Kunskapssammanställning; FjällMistrarapport nr 3: Umeå, Sweden, 2004.

18. Sandström, C.; Lindvall, A. Regional Förvaltning av Rovdjur i Västerbotten och Norrbotten: Om Likheter Och Skillnader ur ett Samförvaltningsperspektiv; FjällMistrarapport: Umeå, Sweden, 2006.

19. Sandström, C.; Widmark, C. Stakeholders' perceptions of consultations as tools for co-management: A case study of the forestry and reindeer herding sectors in northern Sweden. For. Policy Econ. 2007, 10, $25-35$.

20. Sandström, C.; Moen, J.; Widmark, C.; Danell, Ö. Progressing toward Co-management through collaborative learning: Forestry and reindeer husbandry in dialogue. Int. J. Biodivers. Sci. Manag. 2006, 2, 326-333. [CrossRef]

21. Zachrisson, A. Länsstyrelsernas Förvaltning av Jakt Och Fiske i Fjällen. LIKHETER Och Skillnader; FjällMistrarapport nr. 5: Umeå, Sweden, 2004.

22. Ericsson, G.; Eriksson, T.; Laitila, T. Delrapport Om Jakt Och Fiske: Omfattning, Betydelse Och Förvaltning; FjällMistrarapport: Umeå, Sweden, 2005.

23. Eriksson, T.; Andersson, J.; Byström, P.; Hörnell-Willebrand, M.; Laitila, T.; Sandström, C.; Willebrand, T. Fish and wildlife in the Swedish mountain region resources, use and management. Int. J. Biodivers. Sci. Manag. 2006, 2, 334-342. [CrossRef]

24. Sandström, C. Institutional Dimensions of Comanagement: Participation, Power, and Process. Soc. Nat. Resour. 2009, 22, 230-244. [CrossRef] 
25. Zachrisson, A. Deliberative democracy and co-management of natural resources: The case of Funäsdalen snowmobile regulation area. Int. J. Commons 2010, 4, 273-292. [CrossRef]

26. Eckerberg, K.; Zachrisson, A.; Mårald, G. samverkan i Bottenvikens Vattendistrikt: Analys av Vattenrådsarbetet, Report to the Norrbotten County Administration; Länsstyrelsen Norrbotten: Luleå, Sweden, 2012.

27. Sverdrup, H.; Belyazid, S.; Koca, D.; Jönsson-Belyazid, U.; Stjernquist, I. Miljömål i Fjällandskapet: En Syntes av Problemställningar Knutna Till Förvaltningen av en Begränsad Resurs; Rapport 6366; Naturvårdsverket: Stockholm, Sweden, 2010.

28. Scott, T.A. Is Collaboration a Good Investment? Modeling the link between funds given to collaborative watershed councils and water quality. J. Public Adm. Res. Theory 2016, 26, 769-786. [CrossRef]

29. Van Huijstee, M.M.; Francken, M.; Leroy, P. Partnerships for sustainable development: A review of current literature. Environ. Sci. 2007, 4, 75-89. [CrossRef]

30. Shen, L.; Tam, V.W.; Gan, L.; Ye, K.; Zhao, Z. Improving sustainability performance for public-privatepartnership (PPP) projects. Sustainability 2016, 8, 289-304. [CrossRef]

31. Lafferty, W.M. Sustainable Communities in Europe; Earthscan: London, UK, 2001.

32. Lafferty, W.M.; Meadowcroft, J. Implementing Sustainable Development: Strategies and Initiatives in High Consumption Societies; Oxford University Press: Oxford, UK, 2000.

33. Lijphart, A. Consensus and consensus democracy: Cultural, structural, functional and rational choice explanations. Scand. Political Stud. 1998, 21, 99-108. [CrossRef]

34. Emerson, K.; Nabatchi, T.; Balogh, S. An integrative framework for collaborative governance. J. Public Adm. Res. Theory 2012, 22, 1-29. [CrossRef]

35. Wondolleck, J.M.; Yaffee, S.L. Making Collaboration Work: Lessons from Innovation in Natural Resource Management; Island Press: Washington, DC, USA, 2000.

36. Wondolleck, J.M.; Yaffee, S.L. Collaborative ecosystem planning processes in the United States: Evolution and challenges. Environments 2003, 31, 59-72.

37. Thomas, C.W.; Koontz, T.M. Research designs for evaluating the impact of community-based management on natural resource conservation. J. Nat. Resour. Policy Res. 2011, 3, 97-111. [CrossRef]

38. Koontz, T.M.; Thomas, C.W. What do we know and need to know about the environmental outcomes of collaborative management? Public Adm. Rev. 2006, 66, 111-121. [CrossRef]

39. Wagner, C.L.; Fernandez-Gimenez, M. Does community-based collaborative resource management increase social capital? Soc. Nat. Resour. 2008, 21, 324-344. [CrossRef]

40. Leach, W.D.; Sabatier, P.A. Are trust and social capital the keys to success? Watershed partnerships in California and Washington. In Swimming Upstream: Collaborative Approaches to Watershed Management; Sabatier, P.A., Focht, W., Lubell, M., Trachtenberg, Z., Vedlitz, A., Matlock, M., Eds.; MIT Press: Cambridge, MA, USA, 2005; pp. 233-258.

41. Emerson, K.; Nabatchi, T. Evaluating the productivity of collaborative governance regimes: A performance matrix. Public Perform. Manag. Rev. 2015, 38, 717-747. [CrossRef]

42. Koontz, T.M.; Steelman, T.A.; Carmin, J.; Korfmacher, K.S.; Moseley, C.; Thomas, C.W. Collaborative Environmental Management: What Roles for Government? Resources for the Future: Washington, DC, USA, 2004.

43. UNEP \& UNWTO. United Nations Environment Programme (UNEP) and United Nations World Tourism Organization (UNWTO). In Making Tourism more Sustainable. A Guide for Policy Makers; UNEP \& UNWTO: Nairobi, Kenya, 2005.

44. Eckerberg, K.; Bjärstig, T.; Zachrisson, A. Incentives for Collaborative Governance: Top-Down and Bottom-Up Initiatives in the Swedish Mountain Region. Mt. Res. Dev. 2015, 35, 289-298. [CrossRef]

45. Kvale, S.; Brinkmann, S. Interviews: Learning the Craft of Qualitative Research Interviewing; Sage: Newcastle upon Tyne, UK, 2009.

46. Anderson, R. Thematic Content Analysis (TCA). Descriptive Presentation of Qualitative Data. Available online: https://s3.amazonaws.com/academia.edu.documents/36098984/Thematic_Content_Analysis_ manuscript.pdf?AWSAccessKeyId=AKIAIWOWYYGZ2Y53UL3A\&Expires $=1502912717 \&$ Signature $=$ fxOWrFnWGCOHzWcZxkOkTDoc5Ys\%3D\&response-content-disposition=inline\%3B\%20filename\% 3DTHEMATIC_CONTENT_ANALYSIS_on_Microsoft_W.pdf (accessed on 3 January 2017).

47. Neuendorf, K.A. The Content Analysis Guidebook; Sage: London, UK, 2016. 
48. Christie, P. Observed and perceived environmental impacts of marine protected areas in two Southeast Asia sites. Ocean Coast. Manag. 2005, 48, 252-270. [CrossRef]

49. Pollnac, R.B.; Pomeroy, R.S. Factors influencing the sustainability of integrated coastal management projects in the Philippines and Indonesia. Ocean Coast. Manag. 2005, 48, 233-251. [CrossRef]

50. Scott, T. Does collaboration make any difference? Linking collaborative governance to environmental outcomes. J. Policy Anal. Manag. 2015, 34, 537-566. [CrossRef]

51. Bjärstig, T.; Zachrisson, A.; Eckerberg, K. Collaborative governance and the role of the public officers. Natural resource management in the Swedish mountains. Scand. J. Public Admin. under review.

52. Moon, S.G.; Jeong, S.Y.; Choi, Y. Moderating effects of trust on environmentally significant behavior in Korea. Sustainability 2017, 9, 415-434. [CrossRef]

53. Bjärstig, T.; Sandström, C. Public-private partnerships in a Swedish rural context. J. Rural Stud. 2017, 49, 58-68. [CrossRef]

54. Amatya, L.K.; Cuccillato, E.; Haack, B.; Shadie, P.; Sattar, N.; Bajracharya, B.; Shrestha, B.; Caroli, P.; Panzeri, D.; Basani, M.; et al. Improving Communication for Management of Social-ecological Systems in High Mountain Areas: Development of Methodologies and Tools-The HKKH Partnership Project. Mt. Res. Dev. 2010, 30, 69-79. [CrossRef]

55. Salerno, F.; Cuccillato, E.; Caroli, P.; Bajracharya, B.; Manfredi, E.C.; Viviano, G.; Thakuri, S.; Flury, B.; Basani, M.; Panzeri, D. Experience with a Hard and Soft Participatory Modeling Framework for Social-Ecological System Management in Mt Everest (Nepal) and K2 (Pakistan) Protected Areas. Mt. Res. Dev. 2010, 30, 80-93. [CrossRef]

56. De Vente, J.; Reed, M.; Stringer, L.; Valente, S.; Newig, J. How does the context and design of participatory decision making processes affect their outcomes? Evidence from sustainable land management in global drylands. Ecol. Soc. 2016, 21, 24. [CrossRef]

(C) 2017 by the author. Licensee MDPI, Basel, Switzerland. This article is an open access article distributed under the terms and conditions of the Creative Commons Attribution (CC BY) license (http:/ / creativecommons.org/licenses/by/4.0/). 